\title{
Life cycle cost profitability of biomass power plants in South Africa within the international context
}

\author{
Henning R Visser ${ }^{1}$, George Alex Thopi ${ }^{1}$, Alan Brent ${ }^{2,3}$ \\ ${ }^{1}$ Department of Engineering and Technology Management, University of Pretoria \\ ${ }^{2}$ Chair in Sustainable Energy Systems, School of Engineering and Computer Science, \\ Victoria University of Wellington \\ ${ }^{3}$ Department of Industrial Engineering, Stellenbosch University
}

\begin{abstract}
South Africa's renewable energy programme has been widely considered a success. Biomass is one of the selected technologies, on which capacity and tariff caps are set in place. It is unclear whether the price caps allow for sufficient profits for private roleplayers. The aim of the study is to investigate the potential profit margins for biomass power plant companies entering the programme. Costs throughout the lifespan of the power purchase agreement were determined by using the Levelised Cost of Electricity (LCOE) metric. The method used cost inputs which were determined using a mixture of local and international indicators for three scenarios, the worst case (WC) scenario representing highest input costs, the most likely case (MLC) scenario representing median costs, and best case (BC) scenario representing lowest input costs. The results show that that the WC, MLC and BC LCOE for biomass power plants in South Africa are 3.53 ZAR/kWh (0.235 USD/kWh), $1.30 \mathrm{ZAR} / \mathrm{kWh}(0.086 \mathrm{USD} / \mathrm{kWh})$ and $0.78 \mathrm{ZAR} / \mathrm{kWh}(0.052$ USD/kWh), respectively. In all three scenarios, the bulk of the cost constitutes delivered fuel costs. Considering sales tariffs at ZAR1.475/kWh, profit margins for WC, MLC and BC scenarios were determined as $-139 \%, 12 \%$ and $47 \%$, respectively. These figures compare favourably with China, the United States of America, and Europe in general, opposed to Canada, where higher profit margins are achievable.
\end{abstract}

Keywords: Renewable Energy, Biomass electricity, Independent Power Producer, LCOE, Profit margin

\section{Introduction}

South Africa's current renewable energy programme based on an auction-based model was initiated in 2011 and is still on going. The programme caters for six different renewable technologies of which biomass is also included. The initial seeds of South Africa's energy policy took shape following a White Paper published in 1998 (Martin and Winkler, 2014), stating the following objectives: increase access to affordable energy, improve energy governance, stimulate economic development, manage energy-related environmental impacts, and secure energy supply through diversity (Martin and Winkler, 2014). With these objectives in mind, government plans its long-term policy outlooks based on its Integrated Resource Plan (IRP), promulgated in $2011^{1}$ (Department of Energy, 2013). The IRP projects future electricity demand within South Africa (the Base Case) and prescribes the technologies (and in what proportion) that should make up the generation mix. These technologies include traditional coal, nuclear, gas and renewable energy (RE).

In South Africa, Independent Power Producers (IPPs) facilitate most of the RE capacity, which takes some of the investment burden off the government, indicated by the R245bn ${ }^{2}$ worth of private investments in RE procured between 2011 and 2016 (Fin24, 2017). Further to this, severe electricity supply constraints, and increasing environmental

\footnotetext{
${ }^{1} 2013$ and 2016 versions are available, but has not officially been adopted with the 2016 version still in draft form

21 US dollar (USD) = 15 South African Rand (ZAR), based on September 2018 exchange rates.
} 
awareness, has led to fast-tracking the procurement and construction of RE in South Africa. Under the Renewable Energy Independent Power Producer Procurement Programme (REIP4) ${ }^{3}$, prospective IPPs are invited to submit a tender for the delivery of energy output ( $\mathrm{kWh}$ ) from a specific technology for a period of 20 years at a specific price (ZAR/kWh). As at the end of 2017, substantial renewable energy has been procured through the REIP4 under four (4) bidding windows as shown in Table 1 (Department of Energy, 2016; Department of Energy, 2015a).

Table 1: Renewable energy procured under the REIP4

\begin{tabular}{|l|c|c|c|c|c|c|}
\hline & \multicolumn{7}{|c|}{ MW procured per bidding round } \\
\hline Technology & BW 1 & BW 2 & BW 3 & BW 3.5 & BW 4 & BW1S \\
\hline Onshore Wind & $649 \mathrm{MW}$ & $559 \mathrm{MW}$ & $787 \mathrm{MW}$ & - & $1363 \mathrm{MW}$ & $9 \mathrm{MW}$ \\
\hline Solar PV & $627 \mathrm{MW}$ & $417 \mathrm{MW}$ & $435 \mathrm{MW}$ & - & $813 \mathrm{MW}$ & $30 \mathrm{MW}$ \\
\hline Solar CSP & $150 \mathrm{MW}$ & $50 \mathrm{MW}$ & $400 \mathrm{MW}$ & $200 \mathrm{MW}$ & - & \\
\hline Landfill Gas & - & - & $18 \mathrm{MW}$ & - & - & \\
\hline Biomass & - & - & $17 \mathrm{MW}$ & - & $25 \mathrm{MW}$ & $10 \mathrm{MW}$ \\
\hline Small Hydro & - & $14 \mathrm{MW}$ & - & - & $5 \mathrm{MW}$ & \\
\hline Total & $1426 \mathrm{MW}$ & $1040 \mathrm{MW}$ & $1657 \mathrm{MW}$ & - & $2205 \mathrm{MW}$ & $49 \mathrm{MW}$ \\
\hline
\end{tabular}

$\mathrm{BW}=$ Bid window; BW1S = Small projects

Under the REIP4, a bidder must compile a tender document that adheres to certain technology, financial, legal, environmental, and socio-economic criteria (Eberhard and Naude, 2017). Once a tender has been submitted, the proposal is evaluated according to a 70/30 price/non-price determination, where price determinations are evaluated according to the price in $\mathrm{ZAR} / \mathrm{kWh}$ tendered by the bidder, and non-price determinations are primarily of socio-economic value that are qualified through thresholds and scored through targets.

One of the technologies from which RE is procured is biomass power plants. Biomass power plants usually range from $5 \mathrm{MW}$ to $50 \mathrm{MW}$ and meet approximately $1 \%$ of global electricity demand (Lako, 2010). In South Africa, the application of biomass has been slow and isolated on a rural scale (Röder et al, 2017; Mamphweli \& Meyer, 2009). The REIP4 attempts to change this and defines biomass as any one of six types: forest biomass (derived from forests), woody biomass (derived from grass- and croplands), non-woody biomass (derived from grass- and croplands), biomass residue (by-products derived from operations), waste biomass (derived from domestic, commercial, industrial or medical waste) and invasive plant biomass (derived from non-indigenous plant species) (Department of Energy, 2015c).

Since prices tendered constitute a large portion of the tender evaluation procedure, bidders must know with great certainty the cost associated with the plant over its entire life cycle. One method to obtain such costs is the LCOE metric (Sklar-Chik et al., 2016). LCOE (ZAR/kWh) entails breaking the system into different phases and costing each phase. Once all costs have been calculated (in real terms) a LCOE (ZAR/kWh) may be determined to provide a true reflection of return on investment and profits of the original investment. Many papers have attempted to determine the LCOE for biomass power plants (Ouyang and Lin, 2014; International Renewable Energy Agency, 2012; Lako, 2010; Kumar et al., 2008; Kumar et al., 2003). There exist differences in these papers, as to what costs to include under the different costing factors (such as harvesting costs), but

3 The REIP4 is a government programme used to procure renewable energy between 2010 and 2030 and, therefore, decrease dependence on fossil fuels for the country's energy needs as discussed in Walwyn, D. \& Brent, A. (2015). 
the amount and type of cost factors seem to remain consistent throughout the various investigations.

It is unclear what the LCOE is for a South African biomass power plant, in ZAR/kWh, when considering requirements as determined under the REIP4, and how these costs relate to the ZAR/kWh offered as a maximum by the Department of Energy (DoE) under the REIP4. Since the REIP4 aims to attract direct foreign investment, it is also unclear whether the potential profit margins associated with biomass power plants under the REIP4 is sufficient to attract foreign investment. The objective of this paper is therefore to determine potential profit margins offered to biomass project companies through the REIP4, and how this profit margin compares with that of other countries. In order to address the research problem effectively it is argued that the price, in ZAR/kWh, offered by the DoE under the REIP4 allows for a profit margin to exist, and that the profit margin in South Africa is comparable to that of international countries similar to South Africa in terms of (biomass) fuel availability. The fact that two projects have been approved under the REIP4, makes this a reasonable argument.

It is believed that the findings of this investigation will benefit policy making and price determination amongst decision making bodies as well provide private investors a better understanding of the utility scale biomass pricing structure in South Africa. Specifically, the LCOE metric can inform techno-economic analyses undertaken, not only in South Africa, but also in other regions (Limmanee et al, 2017; Abdelhady et al, 2018).

The next section will include a discussion of the approach and background used for the study. Section 3 constitutes the methodological categorisation of LCOE that will involve identifying components critical to the LCOE analysis. This section will also include discussions of international literature relating to biomass LCOE components. Section 4 provides a breakdown of the biomass LCOE component results along with international results for the three scenarios. A detailed discussion of the results in undertaken in section 5 where profit margins for multiple countries/regions are discussed for the each scenario with conclusions being made in section 6 .

\section{Research approach}

In order to address the research objectives, four categories were determined and compared to each other. These are: (1) the South African LCOE using both local and international data, (2) international LCOE using international data, (3) South African sales using South African data, and (4) international sales using international data. The proposed approach is illustrated in Figure 1.

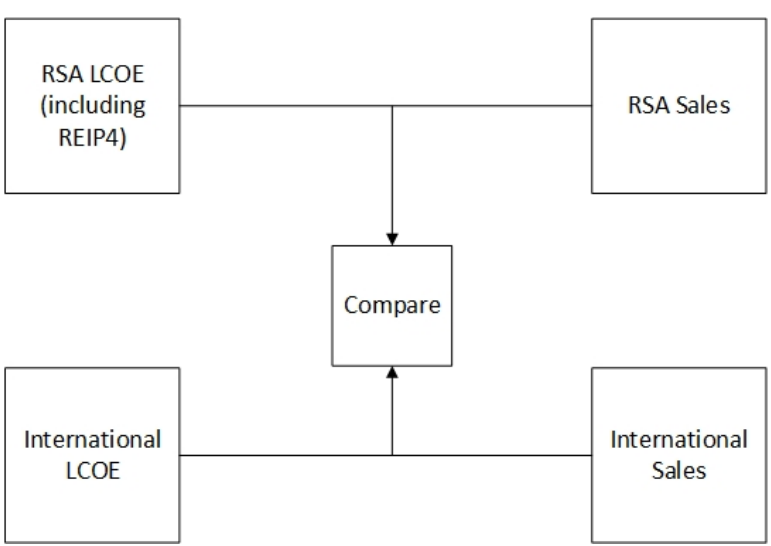

Figure 1: Proposed conceptual approach 
A literature search conducted on South African-based biomass power plants revealed very few academic articles. In fact, authors investigating RE in South Africa (and more specifically RE policy), such as Eberhard et al. (2014), Eberhard (2014), Pegels (2010) and Winkler et al. (2009) only briefly mention biomass as a RE source, whist authors such as Scholvin (2014) and Sebotosi and Pillay (2008) fail to even mention biomass in their respective papers. The lack of academic literature is not surprising considering the generation capacity procured to date. In fact, only two biomass power projects have been procured under the REIP4, namely Mkuze's $16 \mathrm{MW}$ and the Ngodwana Energy Project's $25 \mathrm{MW}$ (Department of Energy, 2015b), providing a total generation capacity of $41 \mathrm{MW}$ procured. This represents $0.81 \%$ of the $5,037 \mathrm{MW}$ procured under the REIP4 (Department of Energy, 2015b; Eberhard et al., 2014). Neither project has to date reached financial close, causing authors to discard biomass as insignificant.

These small generation capacities may be attributed to South Africa's biomass stocks. In comparison to countries such Canada, China, the USA and large portions of the European continent, South Africa does not have abundant biomass resources. For example, South Africa's Department of Agriculture, Forestry and Fisheries (DAFF) estimate that South Africa has approximately 1.27 million ha of afforested areas (Department of Agriculture Forestry and Fisheries, 2015), compared to Europe's total 140.15 million ha, as reported by Verkerk et al. (2011). Academic literature regarding biomass power plants in South Africa is thus not likely to increase substantially over a short period of time, although some attempts are being made. An example of this is the Bio-Energy Atlas (Hugo, 2016) published by the South African Department of Science Technology which, amongst others, investigates the potential of power generation through biomass. According to the report, South African biomass resources can contribute approximately 1,300 $\mathrm{MWe}$ towards South Africa's energy mix. Besides the limited availability of South African biomass literature, it is still necessary to either derive a LCOE for biomass power plants in South Africa through primary data using surveys of existing or near-complete facilities, or secondary data using international studies.

Besides traditional LCOE methodologies, and in order to fully address the research objectives, it is important to understand the REIP4 and what it aims to achieve. Following unsuccessful attempts at procuring renewable energy through RE Feed-In Tariff (REFIT) and CoGeneration FIT (COFIT) programmes (Martin and Winkler, 2014), the DoE initialised the REIP4. The REIP4 enables IPPs to generate and sell electrical energy, but only to the country's single national utility through its Single Buyer Office (SBO), whilst at the same time fulfilling goals set out in government's National Development Plan (NDP). Generating and selling power outside the REIP4 is possible through contracts, such as bilateral agreements (Amatola Green Power, 2016; Bosch Projects, 2015), but these contracts are usually negotiated on a per-project basis and is not considered here. The REIP4's aim of ensuring renewable energy growth along with socio-economic development (Walwyn \& Brent, 2015) differ with the RE programme of developed countries' where supply security and reduction of Greenhouse Gas (GHG) emissions are prioritised (Meyer, 2003). Given the different set of goals between South Africa and developed countries, it is important to establish the REIP4-inclusive LCOE for South Africa and compare that to the rest of the world.

\subsection{International LCOE}

Unlike the South African case, international studies on the LCOE for biomass power plants are more abundant, and include the likes of Ouyang and Lin (2014), the International Renewable Energy Agency (2012), Lako (2010), Kumar et al. (2008), and Kumar et al. (2003). Although authors have subtle differences in reasoning, the general convergence to determine the LCOE is using the following parameters: capital costs, grid connection costs, use-of-system costs, plant availability and start-up costs, operations and 
maintenance (O\&M) costs, biomass costs, harvesting costs, transport costs, plant location costs, ash disposal costs (if not included in O\&M costs), decommissioning costs, and discount rates. In addition to the above parameters, Roth and Ambs (2004) argue that externalities in the form of environmental impacts should also be included.

Certain studies are based on actual power plants, such as the Chinese plants used in the paper by Ouyang and Lin (2014), whilst others are determined using data from suppliers and each country's national agencies, such as the study conducted by the International Renewable Energy Agency (2012). The above-mentioned studies do not (explicitly) cost, or even name other factors, including social and political factors, which may or may not contribute to the LCOE of biomass power plants in those countries. It appears the studies are centred on an assumption that the biomass power plant is either set in a free-market environment with added government incentives, or in a regulated environment where the biomass power plant is protected with feed-in tariffs.

\subsection{South African sales}

The South African electricity market allows for a single buyer of electricity, the SBO, which is positioned within the System Market Operator Division, a division of the country's sole and state-owned utility, Eskom (Khan et al., 2016). This single buyer concept is valid where the ownership boundary (or point of sale) of the electrical energy is situated on a point between the power station and the national grid, and is called a delivery point. Selling of electricity occurs at this point, with all electrical losses (due to reticulation to the delivery point and stepping up of voltages) being taken into account. For the REIP4, original prices and annual price increases are known and fixed at the date of financial close (contract signing) (Department of Energy, 2015c). Knowing the unit prices and availability of the plant over the lifetime of the PPA can result in a fairly reasonable sale forecasts, where possible degree of variability will be as a result of unplanned maintenance.

\subsection{International sales}

International electricity prices are more as a result of free-market principles with added government support from a policy perspective (Wang, 2006; Meyer, 2003; Joskow, 2001). Producing an accurate sales forecast is therefore difficult and uncertain from an international perspective. However, regional governments are securing additional (and more predictable) revenue for RE generation plants through initiatives, such as selling green certificates to carbon-intensive industries (European Commission, 2013). Considering the added support from government in the form of incentives, many international sales tariffs may actually be below the plant's LCOE, and profit margins are sustained through the incentives.

A simplistic way of determining profit margins is through subtracting cost from income. In South Africa's case, this would mean subtracting the LCOE from the sales tariff. More complex ways may be used to increase accuracy. These complex methods account for the fact that sales tariffs are linked to Consumer Price Index (CPI) rates, whilst LCOE considers various longer term price risks (Silinga et al., 2015). Additionally, international case studies need to consider additional revenue streams when considering profit margins; the more complex revenue stream would require subtracting the LCOE from total income (sales tariff added to the incentive).

Comparing results (tariffs as well as sales and subsequent profit margins) provides an insight into the current and potential success of South Africa's REIP4. According to the South African Wind Energy Association (2015), as from October 2015 the REIP4 attracted R193bn worth of private sector investment across its 92 projects. From the R193bn, 28\% or R53.2bn, came from foreign investment (South African Wind Energy Association, 2015). Foreign investment of this magnitude provides insight into the LCOE and profit 
margins of RE technologies globally; companies would not invest in South Africa if it was not economically beneficial to do so. However, investments in biomass power plants remain scarce, necessitating a comparison between South African and global potential profits in the technology.

Considering that international biomass power plants have additional revenue streams in the form of potential heat clients and sales of green certificates (European Commission, 2013), obtaining and comparing the LCOE and sales of biomass power plants participating in the REIP4 with international benchmarks may not be representative. It will, however, reveal whether South Africa's biomass RE policies are favourable for investment, and provide the first step towards answering whether or not companies owning biomass power plants can do so economically without considering other synergies.

\section{Methodological categorisation of LCOE}

\subsection{RSA LCOE (including REIP4)}

Since only two biomass power plants (Mkuzi and the Ngodwana Energy Project) have been procured under the REIP4 (Department of Energy, 2015a), collecting and using primary data for determining the LCOE of South African biomass power plants is not possible (a sample size of two is non-representative). Furthermore, since many international biomass power plants do exist, the availability of abundant sources of secondary data can be used with a high degree of accuracy. Secondary data is generally used for analyses when primary data is not an option, usually due to cost or practicality (Vezzoni, 2015). Costs vary from country to country, making it difficult to compare countries' costs purely using exchange rates. Exchange rates convert Gross Domestic Product (GDP) contributors along with their expenditures to a common currency. However, as noted by the World Bank Group (2011), using exchange rates cannot always be used to compare countries, since they do not take into account the relative purchasing power of currencies in their own countries. A more common method of comparing costs in different countries is by using Purchasing Power Parity (PPP) (World Bank Group, 2011). The LCOE for biomass power plants in South Africa was obtained by using secondary data from both local and international sources, and a combination of exchange rates and PPPs, as shown in Figure 2.

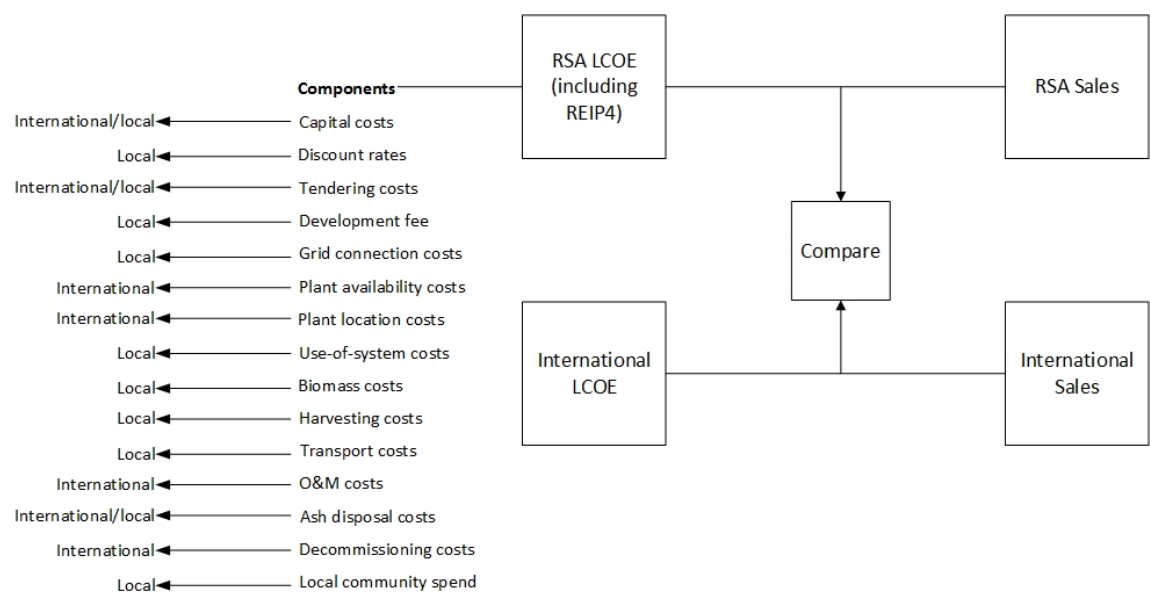

279 Figure 2: Components and sources for determining RSA based costs

280 Each component in Figure 2 is represented by three scenarios, namely: a WC scenario, an MLC scenario, and a BC scenario. Due to a number of LCOE components containing costs as a range, certain sources provided more than one value for a LCOE component, 
based on data obtained and assumptions made. Sources containing more than one cost was categorised, with costs assigned to a scenario based on its impact on the LCOE, with the higher cost associated with the WC. Once costs from all sources were obtained for a component, the median cost for each scenario was determined and used as that component's scenario (WC, MLC and BC) cost. Median costs, as opposed to average costs, were used to eliminate outliers. The three scenarios determine the range of values, and thus the uncertainties associated with the different parameters, and therefore the overall LCOE.

Assumptions used for the analysis in the article were made to simulate as closely as possible a plant entered in the REIP4:

- Net capacity of $25 \mathrm{MWe}$ as this is the maximum allowable capacity under the REIP4 (Eberhard and Naude, 2017);

- Gross capacity of 28 MWe assuming a parasitic load of roughly $10 \%$;

- Inflation rates used for different countries as shown in Table B.1 (Appendix B);

- Currency exchange rates are predetermined according to the Expedited Bidding Window of the REIP4 and is displayed in Table B.2;

- PPP rates were obtained from OECD.stat (2015) and shown in Table B.2;

- A grid availability of $100 \%$ is assumed - this is the availability factor of the grid to take any energy produced by the biomass power plant. Although maintenance is required on these lines from time to time, it is assumed that this maintenance is coordinated in such a way as to coincide with maintenance done on the biomass power plant. Furthermore, it is assumed that unplanned outages will not affect the grid availability factor due to $n-1$ redundancy;

- Turbine maintenance is expected as shown in Table 2. Minor overhauls last 672 hours, with major overhauls lasting 1,344 hours (Latcovich et al., 2005) - overhaul hours are over and above plant availability factors;

- Biomass power plants are situated in close proximity to commercial plantations and processing facilities, where forest biomass and biomass residue originate;

- According to the PPA for the REIP4, the fuel supplier may supply biomass from any of the following sources: forest biomass from sustainable forestry practices, woody biomass mainly from croplands/grasslands, non-woody biomass mainly from croplands/grasslands, biomass residue from existing processing facilities, waste biomass accumulated on landfill sites and invasive plant biomass consisting of non-indigenous plants not specifically planted for honouring the fuel supply agreement with the IPP (Department of Energy, 2015c). Although publications such as the BioEnergy Atlas (Hugo, 2016) has recently seen the light, these publications are still theoretical in nature and has not been verified. Therefore, data contained in the atlas cannot be used and it is for this reason that only forest biomass and biomass residue (as used in the Ngodwana Energy Project) are considered here;

- All costs are in 2015 real terms to coincide with cost assumptions made by the Department of Energy on its Expedited Bidding Window- it is assumed that costs as well as sales will increase with $\mathrm{CPI}$ annually;

- The average distance for transporting biomass from source to plant site is $50 \mathrm{~km}$. Although significantly longer runs are possible it is assumed that possible processing residue is situated nearby and balances out the longer runs for forestry biomass and biomass residue;

- Biomass ash is classified as hazardous (Government, 2013); and

- No Value Added Tax (VAT) or any other form of tax has been taken into account. 
Table 2: Typical steam turbine maintenance schedule

335

336

337

338

339

340

341

342

343

344

345

346

347

348

349

350

351

352

353

354

355

356

357

358

359

360

361

362

363

364

365

366

367

368

369

370

371

372

373

374

375

376

377

378

\begin{tabular}{|l|l|l|}
\hline \multicolumn{1}{|c|}{ Number of hours } & \multicolumn{1}{|c|}{$\begin{array}{c}\text { Years after } \\
\text { commissioning }\end{array}$} & \multicolumn{1}{|c|}{ Type of overhaul } \\
\hline 10,000 & Maximum of 4 & Minor \\
\hline 25,000 & Maximum of 8 & Minor \\
\hline 50,000 & Maximum of 15 & Major \\
\hline 75,000 & Maximum of 20 & Minor \\
\hline
\end{tabular}

Source: (Latcovich et al., 2005)

Each component's LCOE was determined as follow:

\section{- Capital costs and discount rates}

Estimations from sources used were inflated to 2014 prices and converted to ZAR using exchange- and PPP rates. Once inflated and converted to ZAR, prices were scaled to the gross capacity using equation (1) and a scale factor of 0.75 , as proposed by Kumar et al. (2008):

$$
\operatorname{Cost}_{2}=\operatorname{Cost}_{1} x\left(\frac{\text { Capacity }_{2}}{\text { Capacity }_{1}}\right)^{\text {scle factor }-1}
$$

Once scaled, full estimations were determined using three (3) different exchange rate/PPP ratios, namely:

$>W C-60 / 40$, as given by the Department of Energy (2015c);

$>\mathrm{MLC}-45 / 55$, which is the mid-point between the WC and BC;

$>\mathrm{BC}-30 / 70$, which is considered the maximum local content possible, based on communication with turbine manufacturers.

The capital costs LCOE was then determined using the sales predicted throughout the PPA.

Discount rates are used to determine the present value of future costs. For this paper, discount rates were calculated on loan repayments for capital costs, including interest paid during construction. WC, MLC and BC capital costs were split into WC, MLC and BC debt/equity ratios (WC 77.5/22.5, MLC 75/25, BC 72.5/27.5) as proposed by the Central Electricity Regulatory Commission (2013) and the United States. Minerals Management Service (2009). Interest was then calculated during construction on the debt portion of capital costs - interest rates were taken as the historical London Interbank Offered Rates (LIBOR) plus 3.5\%, as observed by Eberhard et al. (2016). The LIBOR rates used are $0.5 \%, 0.3 \%$ and $0.2 \%$ for WC, MLC and BC, respectively. Repayments were calculated using Excel's PMT function and two discount rates per scenario. The first rate is the WC, $M L C$ or $B C$ discount rates, and the second discount rate was set to zero in order to calculate the effect of the discount rate on the LCOE.

\section{- Tendering costs, development fee and grid connection costs}

For tendering fees, percentage of capital costs spent on preparing tenders was obtained from Dalrymple et al. (2005), Sidwell et al. (2008) and the Engineering Council of South Africa (2014); WC, MLC and BC values were determined by calculating the median of WC, MLC and BC scenarios given by the authors.

The REIP4 as run by the Department of Energy (2015c) requests a development fee for qualifying projects. This fee was calculated as $1 \%$ of total project costs. The 
WC, MLC and BC scenarios for capital costs were used to determine the $1 \%$ fee, where after the LCOE was calculated.

Grid connection costs are mostly determined through the vicinity of the power plant in relation to Eskom's main infrastructure. Although Eskom does not disclose project-specific costs, overall costs are disclosed. These costs (from all RE technologies) were used to determine the average cost per project and average cost per MW. Costs were then compared with that of the Ngodwana Energy Project (grid connection costs are included in capital costs), where power is already being exported to the national grid through other means of power generation (TAPPSA Journal, 2013). The plant is situated in close proximity to the utility distribution line, meaning no/little additional infrastructure is required to evacuate generated energy.

\section{- Plant availability and start-up costs}

A plant availability of $92 \%$ was used throughout this paper (International Renewable Energy Agency, 2012). However, the REIP4 requires an availability of at least $75 \%$, and Kumar et al. (2008) proposes an availability of $80 \%$ for the first year of operation. The effect of varying availability factors were analysed for the LCOE. The availability factor is taken as the availability factor for the conversion plant and does not include turbine overhauls. It is also expected that any grid outages will be covered in this availability factor, resulting in the $100 \%$ grid availability assumed.

401

402

403

404

405

406

407

408

409

410

411

412

413

414

415

416

417

418

419

420

421

422

423

424

425

426

427

428

\section{- Plant location and use-of-system costs}

Plants were assumed to be in close proximity to towns and distribution lines, meaning no additional costs are incurred. The REIP4's PPA clarifies that these costs are to be recovered by the IPP on a monthly basis from the SBO.

\section{- Biomass costs}

Biomass costs in South Africa differ greatly from global prices (York Timbers, 2013), since South Africa does not have an abundance of the resource. In contrast to this, residue prices are some of the lowest in the world (York Timbers, 2013). For this reason, only South African sources were used to determine the biomass LCOE. According to the REIP4, a fuel supply agreement has to be in place between the IPP and a fuel supplier guaranteeing a (biomass) fuel supply for at least three years to the biomass power plant (Department of Energy, 2015c). Although the fuel supplier will strive to supply lower value (residue) biomass, guarantees can only be given on whole plantations (including higher value lumber), and prices for both higher- and lower value biomass were therefore used.

The biomass LCOE was derived through the process as stipulated in Figure 3. When converting from original unit $\left(\mathrm{m}^{3}\right)$ to common unit (ton), the conversion factors as proposed by Forestry South Africa (2015) were used. LHV was determined using equation (2), as found in Boundy et al. (2011):

$$
L H V=H H V \times(1-M C)-2.447 \times M C,
$$

where LHV is the Lower Heating Value, HHV is the Higher Heating Value, and MC is the Moisture Content on a wet basis. 


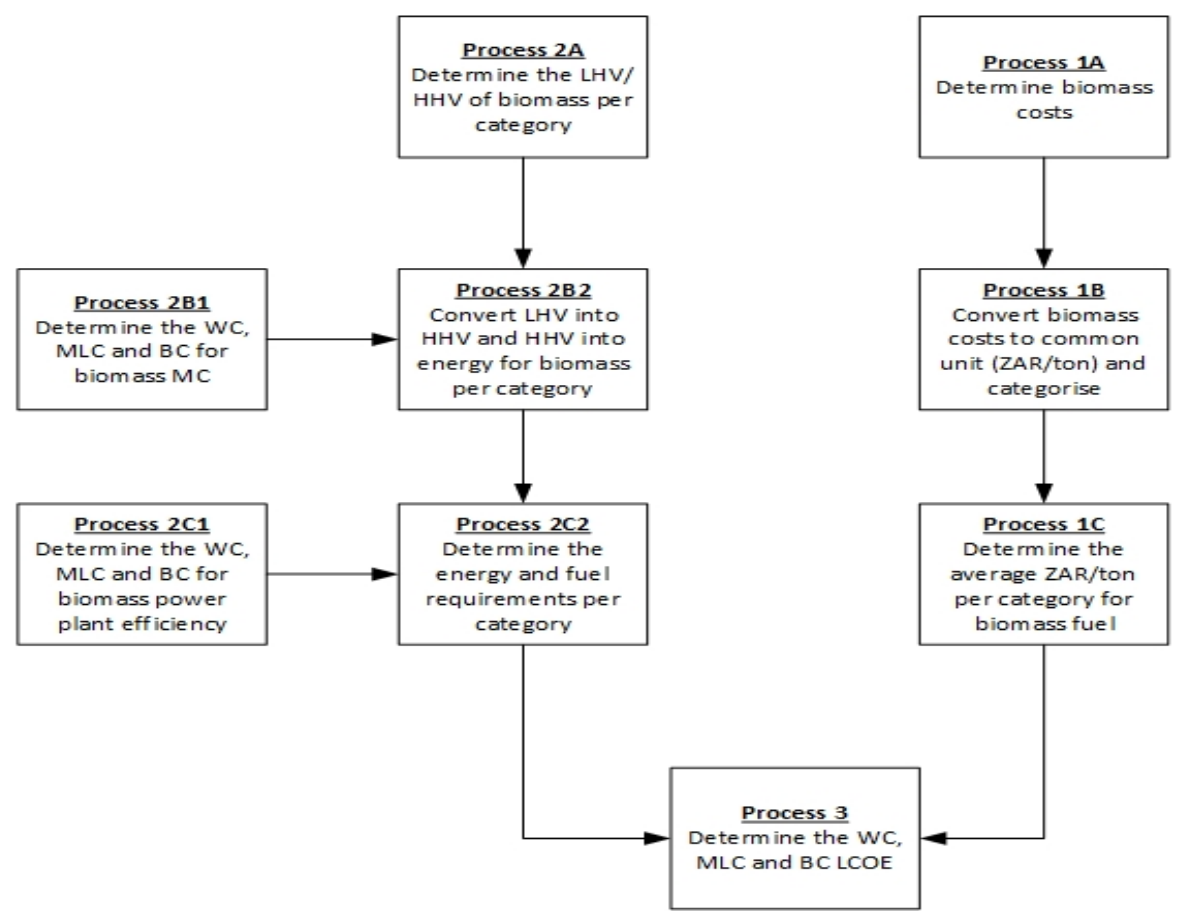

Figure 3: Process for determining the biomass LCOE

\section{- Harvesting costs and transport costs}

Harvesting costs are considered confidential information to most companies, and are thus not easily obtainable. For the harvesting LCOE, 2014 annual results from the South African Forestry Company Limited (SAFCOL) (South African Forestry Company (SOC) Limited, 2014) were used. Although the rates used by SAFCOL may not be representative of the entire industry, SAFCOL rates may be used as a benchmark, due to the high volumes harvested and sold by the company. Volumes (in $\mathrm{m}^{3}$ ) were converted to ton, from where an average rate was determined to obtain the LCOE.

Transport costs not only differ greatly depending on the plant's geographical location, but are of a highly variable nature. WC, MLC and BC rates (ZAR/km/ton) were determined using available data (as discussed in section 4.1.6). From this and based on a $50 \mathrm{~km}$ radius, the LCOE was determined.

\section{- O\&M costs and ash disposal costs}

As with plant availability and start-up costs, these costs are primarily determined by the technology supplier. International results were obtained and converted to ZAR using exchange rates and not PPP. South African labour costs were also not obtained, since it is reasonable to assume that the majority of biomass power plants under the REIP4 will utilise O\&M contracts from foreign companies (denominated in foreign currency) as in the case of the Ngodwana Energy project (Ngodwana Energy, 2015).

Ash disposal costs are included in some studies as part of the O\&M costs, and the $\mathrm{BC}$ scenario was therefore set to zero. Typical ash content was determined for WC and MLC figures (as discussed in section 4.1.7), and this was used to determine (along with the total fuel required) the total ash to be disposed of during the course of the PPA. An average truck payload was used to determine the number of trips required to the nearest hazardous waste dumpsite, from where the ash LCOE was determined. 


\subsection{International LCOE}

The international LCOE was obtained by analysing existing literature. Although international LCOE figures comprise of the same components as those mentioned in the South African LCOE (with the exception of REIP4 specific costs), these were not individually considered. Each country has different factors influencing each component, making a component per component comparison irrelevant. WC, MLC and BC LCOE figures were obtained from mostly the same sources as those used in the South African LCOE analysis (this will ensure a continuity in assumptions) and include: Ouyang and Lin (2014), Kost et al. (2013), the International Renewable Energy Agency (2012), Laleman et al. (2012), Tidball et al. (2010), Borin et al. (2010), Frydas (2010), Kumar et al. (2008), Roth and Ambs (2004) and Kumar et al. (2003). LCOE figures were inflated in the studyspecific currency to 2014 figures, where it was converted to ZAR using 2014 exchange rates. The median of each scenario (WC, MLC and BC) was then used as a representative figure from international sources.

\subsection{South African sales}

South African sales were taken as the maximum allowable tariff under the REIP4 presented by the Department of Energy (2015c). Tariffs are expected to be adjusted following macro-economic conditions once financial close is reached under the Expedited Bidding Window, but will not be adjusted to allow higher or lower Internal Rates of Return (IRRs).

\subsection{International sales}

International tariffs for biomass power plants do not only differ from country to country, but also within countries (Council of European Energy Regulators, 2015). As stated by the European Commission (2013), biomass power plant support schemes are extremely complex and differ from project to project, depending on the specific parameters. Average weighted tariffs were obtained and presented, and a special effort was made to obtain tariffs from the same regions as that of the international LCOE. The sources used include the Council of European Energy Regulators (2015), Xu and Yuan (2015), Lang and Lang (2014), Moore et al. (2013), the US Energy Information Administration (2013), Lapierre and Bellisaire (2011), Government of Nova Scotia (2011) and Couture and Cory (2009).

\subsection{Comparison}

Profit margins were determined by subtracting the LCOE from the sales tariff for both the South African and international scenarios. Determining profit margins in this manner allowed for a simple indication of the project company's (equity holder's) potential rate of return; this, in turn, may be used to assess the viability of the project should the expected return be higher than the project company's Weighted Average Cost of Capital. WC, MLC and BC LCOE, sales tariffs, and profit margins (arising from electricity sales) were compared between South Africa and international studies. It should be noted that not all 
517 international biomass power plants have healthy profit margins due to electricity sales. In 518 fact, allowing for free-market price determination (as is the case in most countries), 519 biomass power plants would run at a loss if electricity sales provided the sole source of 520 revenue. Most of these plants obtain income through the selling of green certificates in by Osterkorn and Lemaire (2009). This additional source of income is not evaluated in this article, since it does not have relevance to the South African case.

\section{Comparative Results}

Using the framework as outlined in the conceptual approach and research methodology, the categories as shown on Figure 1 were analysed.

\subsection{South African LCOE}

In order to determine the LCOE for South African biomass power plants, the expected sales over the lifetime of the PPA (20 years) need to be known. The expected sales (kWh) were determined through the capacity of the plant, the availability of the plant (both biomass conversion technologies and turbine), as well as the number of hours throughout the 20 year period, and was estimated at 3,945,600,000 kWh, which compares well with the Ngodwana Energy (2015) project's statement, namely: 3,969,000,000 kWh.

\subsubsection{Capital costs and discount rates}

WC, MLC and BC values range significantly, depending on the source. Values originally denominated in US\$ are slightly higher than those of other currencies - this may indicate strong PPP relationships between South Africa and the "cheaper" currencies. Furthermore, the average value is slightly higher than the median value in all three scenarios, indicating a heavier lean towards US\$ denominated LCOE values. The Ngodwana Energy (2015) project has a total project cost of ZAR 1.2 million. Taking this into account and an appropriate exchange rate/PPP ratio, an approximate capital LCOE was obtained and estimated at ZAR0.36/kWh, which is higher than the calculated WC scenario and represents the new WC scenario.

Discount rates can represent between $3.49 \%$ and $8.36 \%$ of the total LCOE, depending on the interest rate(s) obtained from the main debt provider(s), which is usually 5 to $10 \%$.

\subsubsection{Tendering costs, development fee and grid connection cost (REIP4 cost)} The tendering LCOE represent between $0.7 \%$ and $2.09 \%$ of the LCOE. For this paper, tendering costs are directly linked to capital costs, although not a direct correlation (environmental costs associated with the tender is likely to be as a result of not only project size but geographical location as well).

The development fee represents between $0.07 \%$ and $0.21 \%$ of the LCOE. Although not significant, the development fee is directly coupled to the capital costs, and reducing capital costs will therefore drive down the development fee.

The grid connection LCOE does not represent a large portion of the LCOE, making up between $0.14 \%$ and $0.57 \%$ of the LCOE. There is, however, a high level of uncertainty regarding these costs, with potential plants closer to national lines needing to invest significantly less than projects further away.

\subsubsection{Plant availability and start-up costs}

A worse availability factor $(<92 \%)$ means the plant is running for shorter periods, and less energy is produced (and sold) than the base case of $92 \%$. These reduced production figures results in larger LCOE cost components, since the normalisation factor decreases. The opposite is true for factors larger than $92 \%$. As a result of the increased/decreased 
LCOE factors, the plant availability factor is extremely important and the single biggest influencing factor when considering the LCOE. Assigning plant availability factors of $75 \%$ for WC (Kumar et al., 2008), 92\% for MLC ,and 100\% for BC results in sales forecasts of $3,201,000,000 \mathrm{kWh}, 3,945,600,000 \mathrm{kWh}$ and 4,296,000,000 kWh, respectively. The new (adjusted) sales impact capital costs, discount rates, grid connection costs, biomass costs, harvesting costs, transport costs, ash disposal costs, decommissioning costs, and revenue.

\subsubsection{Plant location costs and use of system cost}

No additional location costs are assumed. The use-of-system costs are recovered from the SBO, and do not add to the LCOE.

\subsubsection{Biomass costs}

Biomass cost is the single biggest contributor to the overall LCOE, contributing between $32.09 \%$ and $42 \%$. Furthermore, the WC value is unlikely to realise since this represents $76.85 \%$ of the maximum allowable sales tariff offered by the DoE.

Comparing same-source prices over different periods (Forestry Economic Services, 2005) that biomass prices generally increase by rates larger than CPI. This may present a significant obstacle for potential bidders that do not own raw material for the biomass power plant. Unless a fuel supply agreement is entered into fixing biomass prices and price escalations (according to $\mathrm{CPI}$ ), the biomass power plant will see an annual decrease in profit. Both current and historic biomass prices were included to account for any anomalies within a certain year.

\subsubsection{Harvesting and transport costs}

Harvesting is another significant LCOE element, contributing between $6.95 \%$ and $12.95 \%$ of the final LCOE. Various factors influence harvesting costs, such as chipping lumber infield or on-site and manual harvesting versus mechanised harvesting. It is therefore evident that no simple choice exists for the biomass power plant in terms of harvesting with the figures a highly variable one.

Transport costs can represent between $4.74 \%$ and $18.80 \%$ of the final LCOE, based on a supply distance of $50 \mathrm{~km}$ and rates, as suggested by Kgope et al. (2015) and Mugido et al. (2014). Major contributing factors influencing the transport LOCE include the size of the plant (a larger plant will require more fuel, increasing the radius of supply), the location of the plant with relation to the fuel supply, and the road infrastructure.

\subsubsection{O\&M costs and ash disposal costs}

The O\&M LCOE represents between $3.17 \%$ and $12.58 \%$ of the overall LCOE, based on data from Ouyang and Lin (2014), Laleman et al. (2012), the International Renewable Energy Agency (2012), Borin et al. (2010), Kumar et al. (2008), Caputo et al. (2005), Kumar et al. (2003) and Voivontas et al. (2001). Plant sizes were not scaled, since the complexity of running biomass power plants are assumed to be consistent, regardless of size. The results indicate that O\&M costs are neither correlated to the country of the plant or the size of the plant. With the BC ash disposal LCOE set to zero (some studies include this in O\&M costs), the WC and MLC values represent between $0.25 \%$ and $0.75 \%$ of the LCOE.

\subsubsection{Decommissioning costs}

Decommissioning costs represent between $0.38 \%$ and $1.5 \%$ of the final LCOE. Some plants may opt to enter another PPA after the conclusion of the REIP4-offered PPA, resulting in decommissioning costs being replaced by refurbishment costs. 
Annual socio-economic spend is determined as $1 \%$ of total sales, and represent between $0.42 \%$ and $1.96 \%$ of the LCOE.

\subsubsection{Summary of the South African LCOE}

630

631

Significant gaps exist between the WC, MLC and BC values. MLC and BC scenario components have more or less the same representation in the total LCOE, with the WC component contributions differing slightly.

According to the International Renewable Energy Agency (2012), delivered fuel costs can make up between $46 \%$ and $70 \%$ of the LCOE, whilst Ouyang and Lin (2014) puts this figure at between $60 \%$ and $70 \%$. The results are consistent with these findings, with WC representing $63.13 \%$, MLC representing $63.26 \%$ and BC a lower $45.85 \%$ of the LCOE. The results are however not consistent with the assertion of International Renewable Energy Agency (2012) that O\&M costs represent between $1 \%$ and $6 \%$ of the total LCOE; only the WC value is in this range. This could be due to over-valuing other components, bringing the total contribution down. The results are also not consistent with the assertion of Kumar et al. (2008) that capital costs will represent between $39 \%$ and $42 \%$ of the LCOE; current projections are a maximum of $20.86 \%$. This will, however, change if harvesting equipment is purchased, bringing harvesting costs down but increasing capital costs. The single biggest component influencing the LCOE is the plant availability factor, as stated in section 4.1.6. This is due to the fact that the plant availability factor directly influences sales of electricity, which, in turn, directly influences the LCOE of a number of different components.

Figure 4 and table 3 indicates the proportional LCOE values. As can be seen, similar patterns exist for the WC, MLC and BC scenarios, with only plant availability factors, harvesting, transport and O\&M costs providing pattern differences. Overall, the WC and BC figures are deemed likely to represent outlier cases in true South African biomass power plants, with the MLC representing the possible median.

Table 3: South African LCOE

\begin{tabular}{|c|c|c|c|c|c|c|}
\hline Component & WC & $\begin{array}{c}\text { Portion of } \\
\text { total - WC }\end{array}$ & MLC & $\begin{array}{c}\text { Portion of } \\
\text { total - MLC }\end{array}$ & BC & $\begin{array}{c}\text { Portion of } \\
\text { total - } \mathbf{B C}^{\mathbf{4}}\end{array}$ \\
\hline Capital costs & 0.364 & $10.30 \%$ & 0.211 & $16.23 \%$ & 0.186 & $20.86 \%$ \\
\hline Discount rates & 0.123 & $3.49 \%$ & 0.095 & $7.30 \%$ & 0.074 & $8.36 \%$ \\
\hline Tendering costs & 0.025 & $0.70 \%$ & 0.021 & $1.63 \%$ & 0.019 & $2.09 \%$ \\
\hline Development fee & 0.003 & $0.07 \%$ & 0.002 & $0.16 \%$ & 0.002 & $0.21 \%$ \\
\hline Grid connection costs & 0.005 & $0.14 \%$ & 0.005 & $0.39 \%$ & 0.005 & $0.57 \%$ \\
\hline Plant availability costs & 0.616 & $17.44 \%$ & - & $0.00 \%$ & $(0.056)$ & $6.32 \%$ \\
\hline Plant location costs & - & $0.00 \%$ & - & $0.00 \%$ & - & $0.00 \%$ \\
\hline Use-of-system costs & - & $0.00 \%$ & - & $0.00 \%$ & - & $0.00 \%$ \\
\hline Biomass costs & 1.133 & $32.09 \%$ & 0.545 & $42.00 \%$ & 0.304 & $34.16 \%$ \\
\hline Harvesting costs & 0.432 & $12.24 \%$ & 0.168 & $12.95 \%$ & 0.062 & $6.95 \%$ \\
\hline Transport costs & 0.664 & $18.80 \%$ & 0.108 & $8.31 \%$ & 0.042 & $4.74 \%$ \\
\hline O\&M costs & 0.112 & $3.17 \%$ & 0.112 & $8.63 \%$ & 0.112 & $12.58 \%$ \\
\hline Ash disposal costs & 0.027 & $0.75 \%$ & 0.003 & $0.25 \%$ & 0 & $0.0 \%$ \\
\hline Decommissioning & 0.013 & $0.38 \%$ & 0.013 & $1.02 \%$ & 0.013 & $1.50 \%$ \\
\hline costs & 0.015 & $0.42 \%$ & 0.015 & $1.14 \%$ & 0.015 & $1.96 \%$ \\
\hline
\end{tabular}

${ }^{4}$ Absolute values for plant availability costs were used in the BC scenario to determine proportions in Figure 4 


\begin{tabular}{|c|c|c|c|c|c|c|}
\hline Component & WC & $\begin{array}{l}\text { Portion of } \\
\text { total - WC }\end{array}$ & MLC & $\begin{array}{c}\text { Portion of } \\
\text { total - MLC }\end{array}$ & BC & $\begin{array}{c}\text { Portion of } \\
\text { total - BC }\end{array}$ \\
\hline LCOE & 3.531 & & 1.298 & & 0.778 & \\
\hline
\end{tabular}

657

658

659 Figure 4: LCOE proportion 


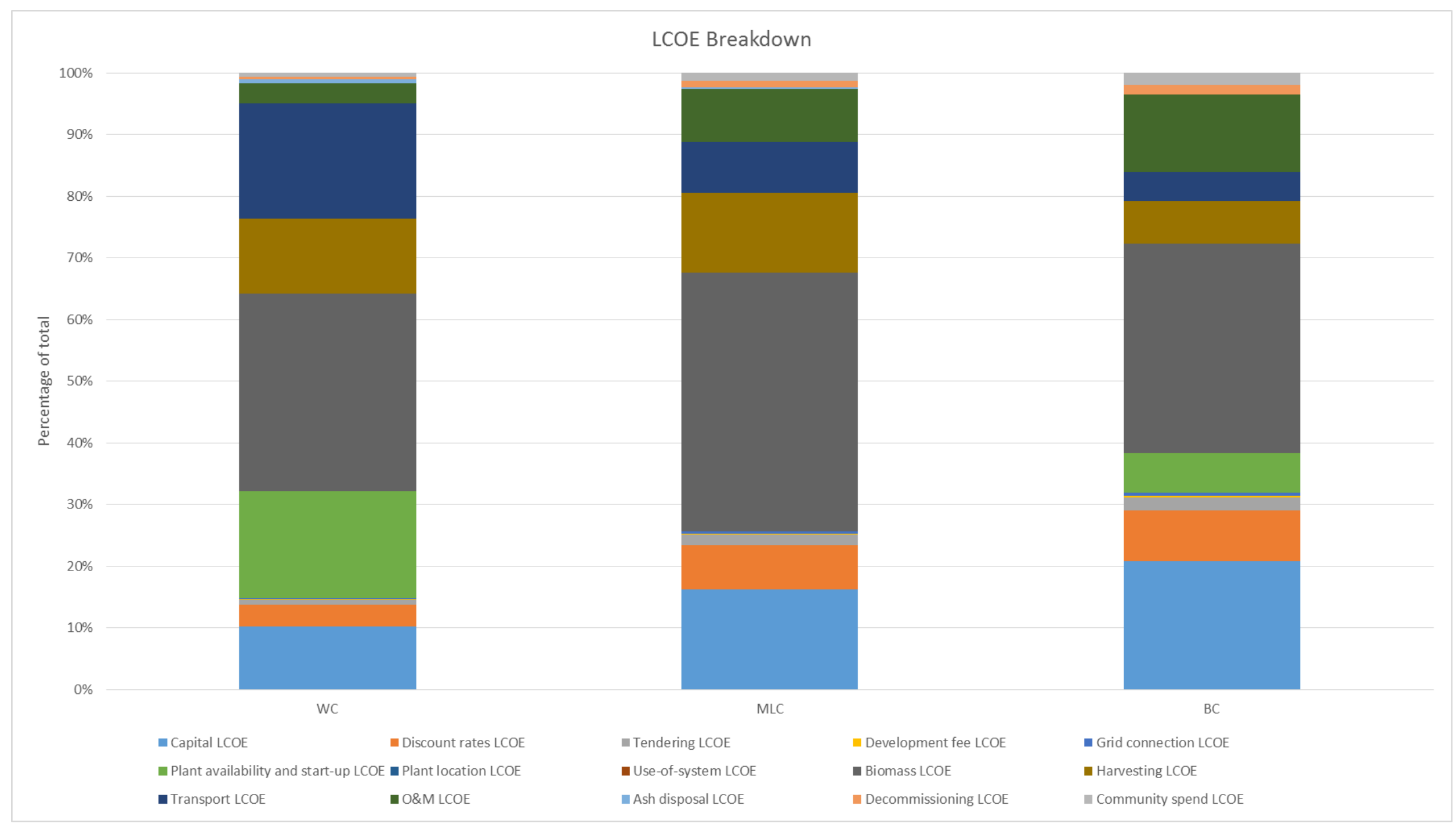


12

\subsection{International LCOE}

The range between international LCOE WC, MLC and BC figures are significantly less than the South African LCOE, with one possible reason being the fact that many international studies either work from primary data or have a bigger secondary data database. Taking this into consideration, one can still see the MLC values for South Africa are in the same region as the BC scenario of the international LCOE (as shown in Table 4). For the international LCOE, the United States and China have comparable LCOE figures. Other regions, denoted as "Other", indicate a large variety in LCOE values.

Table 4: International LCOE (refer to Appendix A)

\begin{tabular}{|l|c|c|c|}
\hline \multicolumn{1}{|c|}{ Country } & WC (ZAR/kWh) & MLC (ZAR/kWh) & BC (ZAR/kWh) \\
\hline Europe & 2.363 & 2.034 & 1.758 \\
\hline Canada & 1.012 & 0.883 & 0.840 \\
\hline United States & 1.524 & 1.359 & 1.194 \\
\hline China & 1.576 & 1.497 & 1.419 \\
\hline Other & 3.400 & 2.402 & 0.835 \\
\hline OVERALL & $\mathbf{1 . 6 7 1}$ & $\mathbf{1 . 5 7 7}$ & $\mathbf{1 . 3 0 6}$ \\
\hline
\end{tabular}

\subsection{South African sales}

The WC, MLC and BC sales are set at ZAR1.475/kWh, which is the rate offered by the DoE under the REIP4. Using the maximum tariff is validated through the limited competitive bids received thus far under the REIP4.

\subsection{International sales}

Large differences exist between WC, MLC and BC values in Europe, with Canada, China and the United States not showing any difference (as shown in Table 5). It should be reiterated that most international biomass power plants rely on either additional revenue streams (such as green certificates) or government support, in addition to selling electricity at market prices. This has not been taken into account here.

Table 5: International sales tariffs (refer to Appendix A)

\begin{tabular}{|l|c|c|c|}
\hline \multicolumn{1}{|c|}{ Country } & WC (ZAR/kWh) & MLC (ZAR/kWh) & BC (ZAR/kWh) \\
\hline Europe & 0.794 & 1.325 & 1.855 \\
\hline Canada & 1.571 & 1.591 & 1.611 \\
\hline China & 1.546 & 1.546 & 1.546 \\
\hline United States & 1.280 & 1.280 & 1.280 \\
\hline OVERALL & $\mathbf{1 . 2 8 1}$ & $\mathbf{1 . 3 2 5}$ & $\mathbf{1 . 8 2 7}$ \\
\hline
\end{tabular}

\subsection{Comparison of results}

Table 6 indicates a comparison between LCOE, sales tariff, and (potential) profit margin for various countries.

31 Table 6: Comparison of LCOE, sales tariff and profit margin

\begin{tabular}{|c|l|c|c|c|}
\hline Country & Description & Worst Case & Most Likely Case & Best Case \\
\hline \multirow{3}{*}{ South Africa } & LCOE (ZAR/kWh) & 3.531 & 1.298 & 0.778 \\
\cline { 2 - 5 } & Sales tariff (ZAR/kWh) & 1.475 & 1.475 & 1.475 \\
\cline { 2 - 5 } & Profit Margin (ZAR/kWh) & $(2.056)$ & 0.177 & 0.697 \\
\hline
\end{tabular}




\begin{tabular}{|c|c|c|c|c|}
\hline Country & Description & Worst Case & Most Likely Case & Best Case \\
\hline & Profit Margin (\%) & $-139 \%$ & $12 \%$ & $47 \%$ \\
\hline \multirow{4}{*}{ Europe } & LCOE (ZAR/kWh) & 2.363 & 2.034 & 1.758 \\
\hline & Sales tariff (ZAR/kWh) & 0.794 & 1.325 & 1.855 \\
\hline & Profit Margin (ZAR/kWh) & $(1.569)$ & $(0.709)$ & 0.097 \\
\hline & Profit Margin (\%) & $-197 \%$ & $-54 \%$ & $5 \%$ \\
\hline \multirow{4}{*}{ China } & LCOE (ZAR/kWh) & 1.576 & 1.497 & 1.419 \\
\hline & Sales tariff (ZAR/kWh) & 1.546 & 1.546 & 1.546 \\
\hline & Profit Margin (ZAR/kWh) & $(0.030)$ & 0.050 & 0.128 \\
\hline & Profit Margin (\%) & $-2 \%$ & $3 \%$ & $8 \%$ \\
\hline \multirow{4}{*}{ Canada } & LCOE (ZAR/kWh) & 1.012 & 0.883 & 0.840 \\
\hline & Sales tariff (ZAR/kWh) & 1.571 & 1.591 & 1.611 \\
\hline & Profit Margin (ZAR/kWh) & 0.559 & 0.708 & 0.770 \\
\hline & Profit Margin (\%) & $36 \%$ & $44 \%$ & $48 \%$ \\
\hline \multirow{4}{*}{ United States } & LCOE (ZAR/kWh) & 1.524 & 1.359 & 1.194 \\
\hline & Sales tariff (ZAR/kWh) & 1.280 & 1.280 & 1.280 \\
\hline & Profit Margin (ZAR/kWh) & $(0.244)$ & $(0.079)$ & 0.086 \\
\hline & Profit Margin (\%) & $-19 \%$ & $-6 \%$ & $7 \%$ \\
\hline \multirow{4}{*}{ 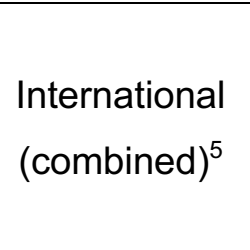 } & LCOE (ZAR/kWh) & 1.671 & 1.577 & 1.306 \\
\hline & Sales tariff (ZAR/kWh) & 1.281 & 1.325 & 1.827 \\
\hline & Profit Margin (ZAR/kWh) & $(0.390)$ & $(0.252)$ & 0.521 \\
\hline & Profit Margin (\%) & $-30 \%$ & $-19 \%$ & $28 \%$ \\
\hline
\end{tabular}

32

33 Considering REIP4 costs and rates, South African biomass power plants potentially have 34 a profit margin of between $-139 \%$ and $47 \%$. According to the results, European biomass 35 power plants can only make a profit of up to $5 \%$ with all $B C$ values used. As stated, these 36 profit margins only consider LCOE inputs and energy sales, and not additional revenue 37 38 39 40 41 42 43 44 45 46 47 48 49 50 streams. Such additional revenue streams typically include additional energy sales in the form of heat for cogeneration plants, and government-backed incentives, such as tax rebates, lower borrowing costs, and sales of green certificates to carbon intensive industries. Such revenue streams are widely implemented and observed as attractive by IPPs, as evidenced by the proposed $300 \mathrm{MW}$ biomass power plant in England (Rogers, 2015). These additional revenue streams are not considered here, seeing as the REIP4 specifically does not allow for them to be implemented. Including them in the costing analysis will result in additional costs being incurred (such as better lagging of steam pipes to preserve heat) and will ultimately result in skew LCOE figures. Chinese biomass power plants can either make a small loss with WC values, or make a reasonable profit (8\%) using BC values. The values reported by Chinese sources for the LCOE and sales tariffs are based on actual values, ensuring a high degree of accuracy. Canadian plants can potentially make profit, no matter what values are used. This is likely due to large (low value) plantation areas available to biomass power plants. Biomass power plants in the

\footnotetext{
${ }^{5}$ Taken as the median of all global sources, see Table A.1 and Table A.2 in Appendix A
} 
United States can either make a loss or small profit, depending on which of WC, MLC or $B C$ values are used. Biomass power plants in the United States are governed by state law, as opposed to federal law, meaning a high degree of variability in results. Combining international results indicate profit margins ranging from $-30 \%$ to +28 , which indicates that global prices have a high degree of variability due to varying factors worldwide and that global prices cannot easily be compared.

\section{Discussion}

Gaining an understanding of the components comprising the LCOE of a biomass power plant in South Africa will help policy-makers determine the most appropriate programme for procuring these plants, as well as what the purchasing price should be to lure investors, whilst providing government with value for money. The current REIP4 has been widely hailed as a great success, due to its transparency and ability to drive down prices across multiple bidding windows (Walwyn and Brent, 2015). Indeed, the current research indicates that government can reduce maximum allowable tariffs for biomass-generated electricity under the BC scenario and this could still allow the technology supplier a reasonable profit margin.

\subsection{South African results}

The South African LCOE range from ZAR0.78/kWh to ZAR3.53/kWh, which suggests a wide range of variability. Considering the MLC, biomass costs (42\%), capital costs $(16.23 \%)$, and harvesting costs $(12.95 \%)$ are the major contributing factors, accounting for over $71 \%$ of the total costs. This indicates that significant effort should be taken to define these costs, since capital costs comprise of multiple smaller costs, focussing on harvesting and biomass costs are deemed easier as these comprise of a single contract each. Decreasing harvesting costs through purchasing equipment (thereby possibly eliminating contractors) would result in increased capital and O\&M costs for the biomass power plant, meaning careful consideration should be given. Biomass costs should be based on energy content and accepted in a size/format agreed by both the biomass supplier and power plant - this should be done to avoid external factors such as moisture content or biomass age, influencing the price. This price should also be fixed before signing the PPA to avoid above-CPI inflation; should this happen (as seen in industry) the biomass power plant's profit margin will reduce until it ultimately runs at a loss.

South African sales are set at a maximum of ZAR1.475/kWh when participating in the REIP4. Although biomass power plants can include tender bids for less than this, this is unlikely due to the limited competition experienced in the bids thus far.

Profit margins for biomass power plants in the REIP4 range from $-139 \%$ (WC) to $47 \%$ (BC). The MLC 12\% profit margin may not lure too many (aggressive) investors on its own merits, whilst the BC $47 \%$ profit margin will result in many investors lining up to build biomass power plants. The factor influencing investors' appetite to invest may well be the fuel supply agreement, since this not only represents the largest LCOE component, but is potentially not under full control of the biomass power plant. Since South Africa has limited biomass resources, there are not many entities owning biomass sources. If the investing company has links to this biomass source (either being the owner or shareholder) then it will gain significant sales to the biomass power plant. Considering that biomass power plants can burn residues (where there is a weak/no market with low prices) then it is not inconceivable to consider that the investing company does not mind low profit margins for the biomass power plant, as it views the power plant merely as a catalyst for selling its "low value" biomass. In this instance, profit margins for biomass power plants become less important for investors as long as the debt provider is satisfied, whilst the investor (equity holder) will strive to keep the biomass costs as high as possible. When considering the results, profit margins closer to $12 \%$ may support this theory, whilst higher profit margins do not. 


\subsection{International results}

The international LCOE ranges from ZAR1.31/kWh to ZAR1.67/kWh, which indicates low variability. A closer look, however, reveals significant differences in country/region specific LCOE values. For example, when considering most likely case values, Europe and "Other" have extremely high LCOE values, well over ZAR2/kWh. In the European case, this may be due to a number of factors, including higher biomass costs due to increased demand for available supply, increased transport costs, and increased grid connection costs due to a larger degree of grid interconnection between countries. Biomass power plants listed as "Other" may have larger LCOE values due to a number of factors, none of which may become apparent without knowledge of which countries are represented. What can be deduced from "Other's" high LCOE range (ZAR0.83/kWh to ZAR3.40 kWh) is that LCOE values differ greatly from one country to another, with no single value representing the industry as a whole. MLC values in the United States and China are more or less consistent with that of South Africa. As in Europe, the main factors influencing LCOE in the US may be biomass costs, transport costs and grid connection costs - the main difference, however, is the LCOE range. Whereas Europe has quite a large range between WC and BC values (ZAR $0.60 / \mathrm{kWh}$ ), the US has approximately half of that (ZAR $0.33 / \mathrm{kWh}$ ). This could be due to more consistent state laws in the US than country specific-laws in Europe. The Chinese LCOE is higher than expected; the main contributing factor is escalating labour costs. Chinese biomass power plants generally employ significantly more people per MW than any other country, and this may largely be due to either perceived lower labour costs or less superior technologies installed. The Canadian LCOE is significantly lower than any other, and this could be due to an abundance of (low value) biomass, thereby decreasing the fuel cost significantly.

Like the LCOE, international sale tariffs appear to be characterised by low variability (ZAR1.28/kWh to ZAR1.83/kWh). However, a closer inspection reveals differences in country-specific sales tariffs. Europe has by far the largest range in sales tariffs (ZAR $0.79 / \mathrm{kWh}$ to ZAR $1.86 / \mathrm{kWh}$ ), and this may largely be due to the fact that European plants can rely on the sale of green certificates, as well as electricity. Another possible reason for the large swing between WC and BC European values is the fact that a lot of biomass power generation plants are actually cogeneration plants, meaning there exists a heat client as well as an electrical client. Canadian and Chinese sales tariffs are more or less the same, with the United States not trailing far behind.

Internationally, profit margins ranging from $-30 \%$ to $+28 \%$ can be expected. Although these profit margins are determined using the full LCOE and only sales from electricity (and not sales from green certificates or heat), the WC profit margin is unlikely. Specifically, European countries are likely to have multiple revenue streams, making an analysis of electricity-sales-only profit margins unreliable. Profit margins in the United States and China are more or less the same and do not invite investor confidence. It is likely that these plants either have additional revenue income (like Europe), or are likely the biomass source owner, meaning lower possible returns are acceptable. The only country with high returns is Canada, with profit margins ranging from $36 \%$ to $48 \%$.

\section{Conclusion}

When comparing South Africa with the rest of the world in terms of biomass power plants, a few points are noticeable.

Firstly, South Africa has a LCOE more or less in the same region as the United States, meaning possible comparisons may be made. On the other hand, the South African LCOE is not comparable with Europe (too expensive) or Canada (too inexpensive). Secondly, South Africa has a sales tariff that is comparable to China and, to a lesser extent, to the United States. 
Lastly, it does not seem as though the REIP4-specific costs have penalised South African plants in any way when profit margins are considered. In fact, considering the MLC scenario and not taking additional revenue streams into account, South Africa has the second highest profit margin behind only Canada. This indicates that although the REIP4 does place additional cost factors onto South African biomass power plants, they are rewarded justly.

This paper set out to determine the LCOE of a biomass power plant in South Africa considering the REIP4 and how this compares to international plants. It was theorised that additional costs as requested by the REIP4 may negatively influence the possible profit margins of South African plants. It was found that the REIP4 does not penalise South African plants, but rather allow (potentially) for larger profit margins than elsewhere in the world.

Although the research objectives have been met, this was done using a fixed exchange rate, and with secondary data. It is recommended that, when enough plants are in existence in South Africa, the same research be carried out using primary data and variable exchange rates, as this would allow for an up-to-date LCOE.

It is theorised that investing companies do have some (financial) stake in the biomass sources supplied to the biomass power plant. It is recommended to investigate this claim, determining the relationship between biomass power plants and biomass source owners. Since only sales tariffs for electricity sold is used to determine international profit margins, it is recommended to conduct research that includes all revenue streams in the profit margins, allowing for better comparisons. The results of LCOE scenarios can be improved further by taking into account the thermal and exergy properties of the fuel type in combination with engine types, and performing either a thermoeconomic or exergoeconomic analysis (Lee at al, 2018; Mergenthaler et al, 2017).

\section{References}

Abdelhady, S., Borello, D., \& Shaban, A. 2018. Techno-economic assessment of biomass power plant fed with rice straw: Sensitivity and parametric analysis of the performance and the LCOE. Renewable Energy, 115, pp 1026-1034.

Amatola Green Power. 2016. Amatola Green Power [Online]. South Africa: Amatola Green Power. Available: http://www.amatolagreenpower.co.za/ [Accessed 23 January 2016].

Borin, S., Levin, T. \& Thomas, V. M. 2010. Estimates of the cost of new electricity generation in the South. Energy Conversion Congress and Exposition (ECCE), 2010 IEEE, 12-16 Sept. 2010. 406-413.

Bosch Projects. 2015. Bio2Watt's Bio-Energy comes to life! Bronkhorstspruit Biogas Plant [Online]. South Africa: Bosch Holdings. Available: http://www.boschprojects.co.za/bio2watts-bio-energy-comes-to-lifebronkhorstspruit-biogas-plant/ [Accessed 23 January 2016].

Boundy, B., Diegel, S. W., Wright, L. \& Davies, S. C. 2011. Biomass Energy Databook: Edition 4, Tennessee: Oak Ridge National Library.

Caputo, A. C., Palumbo, M., Pelagagge, P. M. \& Scacchia, F. 2005. Economics of biomass energy utilization in combustion and gasification plants: effects of logistic variables. Biomass and Bioenergy, 28(1), pp 35-51. 
Central Electricity Regulatory Commission. 2013. Summary of the comments and suggestions received on Approach Paper on Terms and Conditions of Tariff Regulations for the tariff period 1.4.2014 to 31.3.2019. Comments on CERC approach. India: Central Electricity Regulatory Commission.

Council of European Energy Regulators. 2015. Status Review of Renewable and Energy Efficiency Support Schemes in Europe in 2012 and 2013. C14-SDE-44-03, (Brussels, Belgium).

Couture, T. \& Cory, K. 2009. State Clean Energy Policy Analysis (SCEPA) Project: An Analysis of Renewable Energy Feed-In Tariffs in the United States. Technical Report, (United States of America).

Dalrymple, J., Boxer, L. \& Staples, W. 2005. Clients driving innovation: Moving ideas into practice. Cost of tendering: Adding cost without value? Melbourne: Centre for Management Quality Research/CRC Construction Innovation, Royal Melbourne Institute of Technology.

Department of Agriculture Forestry and Fisheries. 2015. Forestry [Online]. South Africa: Department of Agriculture, Forestry and Fisheries. Available: http://www.gov.za/about-sa/forestry [Accessed 17 January 2016].

Department of Energy. 2013. Integrated Resource Plan for Electricity (IRP) 2010-2030 Update Report 2013, Department of Energy

Department of Energy. 2015a. IPP Renewables - Press Centre [Online]. South Africa: Department of Energy. Available: http://www.ipprenewables.co.za/\#page/304 [Accessed 8 November 2015].

Department of Energy. 2015b. Press Centre [Online]. Republic of South Africa: Department of Energy. Available: http://www.ipprenewables.co.za/page/304\#page/304 [Accessed 4 November 2015 2015].

Department of Energy. 2015c. Request for Qualification and Proposals for New Generation Capacity under the REIPP Procurement Programme - Expedited Bidding Window, Department of Energy (Republic of South Africa).

Department of Energy. 2016. Independent Power Producers Procurement Programme (IPPPP), An Overview. Department of Energy (Republic of South Africa).

Eberhard, A. 2014. Feed-in tariffs or auctions? Procuring renewable energy supply in South Africa. Energize RE: Renewable Energy Supplement. ee publishers.

Eberhard, A., Gratwick, K., Morella, E. \& Antmann, P. 2016. Independent Power Projects in Sub-Saharan Africa: Lessons from Five Key Countries, World Bank Publications.

Eberhard, A., Kolker, J. \& Leigland, J. 2014. South Africa's Renewable Energy IPP Procument Program: Success Factors and Lessons. (PPIAF), P.-P. I. A. F. (Washington).

Eberhard, A. \& Naude, R. 2017. The South African Renewable Energy IPP Procurement Programme. Review, Lessons Learned and Proposals to Reduce Transaction Costs. (South Africa). 
Engineering Council of South Africa. 2014. Guideline for Services and Processes for Estimating Fees for Persons Registered in terms of the Engineering Act , 2000 (Act No. 46 of 2000), ECSA (South Africa).

European Commission. 2013. European Commission guidance for the design of renewable energy support schemes. Delivering the internal market in electricity and making the most of public intervention, (Brussels, Belgium).

Fin24. 2017. Eskom clash with renewable sector worrying - analyst. Fin24, 4 April 2017.

Forestry Economic Services. 2005. Commercial Timbers Resources and Roundwood Processing in South Africa. (South Africa).

Forestry South Africa. 2015. South African Forestry and Forest Products Industry Facts 1980 - 2013. South African Forestry and Forest Products Industry Facts, (South Africa).

Frydas, N. F. 2010. Levelised Costs of Power Generation. 4th SEE Energy Dialogue. Thessaloniki: Mott MacDonald.

Government of Nova Scotia. 2011. Community Feed-In Tariff Program. In: Scotia, G. o. N. (ed.) 2010 Renewable Electricity Plan. Nova Scotia, Canada: Government of Nova Scotia.

Government, S. A. 2013. Waste Classification and Management Regulations, National Environmental Management: Waste Act, 2008 (Act No. 59 of 2008), Government Gazette (South Africa).

Hugo, E. 2016. BioEnergy Atlas for South Africa - Synopsis Report. BioEnergy Atlas for South Africa, (Pretoria).

inflation.eu. 2016. Inflation - current and historic inflation by country [Online]. European Union: inflation.eu. Available: http://www.inflation.eu/ [Accessed 15 April 2016 2016].

International Renewable Energy Agency. 2012. Biomass for Power Generation. (Germany).

Joskow, P. L. 2001. California's Electricity Crises. Oxford Review of Economic Policy, 17(3), pp 24.

Khan, M.T., Thopil, G.A. \& Lalk, J. 2016. Review of proposals for practical power sector restructuring and reforms in a dynamic electricity supply industry. Renewable and Sustainable Energy Reviews, 62, pp 326-335.

Kgope, B., Guiney, I., Mathye, M., Maphiri, S., Mampholo, K., Khan, A., Tsubo, M. \& Seabi, F. 2015. Assessment of the potential to produce biochar and its application to South African soils as a mitigation measure. (South Africa).

Kost, C., Mayer, J. N., Thomsen, J., Hartmann, N., Senkpiel, C., Philipps, S., Nold, S., Lude, S., Saad, N. \& Schlegl, T. 2013. Levelized Cost of Electricity Renewable Technologies. (Germany). 
Kumar, A., Cameron, J. B. \& Flynn, P. C. 2003. Biomass power cost and optimum plant size in western Canada. Biomass and Bioenergy, 24(6), pp 445-464.

Kumar, A., Flynn, P. \& Sokhansanj, S. 2008. Biopower generation from mountain pine infested wood in Canada: An economical opportunity for greenhouse gas mitigation. Renewable Energy, 33(6), pp 1354-1363.

Lako, P. 2010. Biomass for Heat and Power. IEA ETSAP - Technology Brief E05,

Laleman, R., Balduccio, L. \& Albrecht, J. The role of biomass in the renewable energy system. 25th International Conference on Efficiency, Cost, Optimization and Simulation of Energy Conversion Systems and Processes (ECOS-2012), 2012.

Lang, M. \& Lang, A. 2014. German Feed-in Tariffs 2014 (from 08) [Online]. Germany: German Energy Blog. Available: http://www.germanenergyblog.de/?page id=16379 [Accessed 21 May 2016].

Lapierre, A. \& Bellisaire, A. 2011. European renewable energy incentive guide - France [Online]. France: Norton Rose Fulbright. Available: http://www.nortonrosefulbright.com/knowledge/publications/66831/europeanrenewable-energy-incentive-guide-france [Accessed 21 May 2016].

Latcovich, J., Astrom, T., Frankhuizen, P., Fukushima, S., Hamberg, H. \& Keller, S. 2005. Maintenance and Overhaul of Steam Tubrines. 38th Annual Conference of the International Association of Engineering Insurers Moscow: IMIA.

Lee, D. Y., Ahn, K. Y., Morosuk, T., \& Tsatsaronis, G. 2017. Exergetic and exergoeconomic evaluation of an SOFC-Engine hybrid power generation system. Energy, 145, pp 810-822.

Limmanee, A., Songtrai, S., Udomdachanut, N., Kaewniyompanit, S., Sato, Y., Nakaishi, M., Kittisontirak, S., Sriprapha, K., \& Sakamoto, Y. 2017. Degradation analysis of photovoltaic modules under tropical climatic conditions and its impacts on LCOE. Renewable Energy, 102 (Part A), pp 199-204.

Mamphweli, S. N. \& Meyer, E. L. 2009. Implementation of the biomass gasification project for community empowerment at Melani village, Eastern Cape, South Africa. Renewable Energy, 34(12), pp 2923-2927.

Martin, B. \& Winkler, H. 2014. Procurement models applied to independent power producer programmes in South Africa. Research Reports Series, Energy Research Centre, U. o. C. T. (Cape Town, South Africa).

Mergenthaler, P., Schinkel, A., \& Tsatsaronis, G. Application of exergoeconomic, exergoenvironmental, and advanced exergy analyses to Carbon Black production. Energy, 137, pp898-907

Meyer, N. I. 2003. European schemes for promoting renewables in liberalised markets. Energy Policy, 31, pp 665-676.

Moore, S., Durant, V. \& Mabee, W. E. 2013. Determining appropriate feed-in tariff rates to promote biomass-to-electricity generation in Eastern Ontario, Canada. Energy Policy, 63, pp 607-613. 
Mugido, W., Blignaut, J., Joubert, M., De Wet, J., Knipe, A., Joubert, S., Cobbing, B., Jansen, J., Le Maitre, D. \& van der Vyfer, M. 2014. Determining the feasibility of harvesting invasive alien plant species for energy. South African Journal of Science, 110(11), pp.

Ngodwana Energy. 2015. Ngodwana Energy. NERSA Public Participation. South Africa: NERSA.

OECD.stat. 2015. PPPs and exchange rates [Online]. Organisation for Economic CoOperation and Development. Available: https://stats.oecd.org/Index.aspx?DataSetCode=SNA TABLE4 [Accessed 19 May 2016].

Osterkorn, M. \& Lemaire, X. 2009. Emerging market for Green Certificates. REEEP, pp.

Ouyang, X. \& Lin, B. 2014. Levelized cost of electricity (LCOE) of renewable energies and required subsidies in China. Energy Policy, 70, pp 64-73.

Pegels, A. 2010. Renewable Energy in South Africa: Potentials, barriers and options for support. Energy Policy, 2010(38), pp 10.

Röder, M., Stolz, N \& Thornley, P. 2017. Sweet energy - Bioenergy integration pathways for sugarcane residues. A case study of Nkomazi, District of Mpumalanga, South Africa. Renewable Energy, 113, pp 1302-1310.

Rogers, D. 2015. Billion dollar plan to give UK world's biggest biomass power station [Online]. United Kingdom: Chartered Institute of Building. Available: http://www.globalconstructionreview.com/news/billion-doll8ar-pl6a2n0-6g4i2ve08u6k-0w6o4r2l08ds/ [Accessed 9 October 2016 2016].

Roth, I. F. \& Ambs, L. L. 2004. Incorporating externalities into a full cost approach to electric power generation life-cycle costing. Energy, 29(12-15), pp 2125-2144.

Scholvin, S. 2014. South Africa's Energy Policy: Constrained by Nature and Path Dependency. Journal of Southern African Studies, 40(1), pp 17.

Sebotosi, A. B. \& Pillay, P. 2008. Renewable energy and the environment in South Africa: A way forward. Energy Policy, 36(2008), pp 5.

Sidwell, T., Dalrymple, J. \& Scuderi, P. 2008. Cost of Tendering. Delivery and Management of Built Assets, (Melbourne).

Silinga, C., Gauché, P., Rudman, J. \& Cebecauer, T. 2015. The South African REIPPP Two-tier CSP Tariff: Implications for a Proposed Hybrid CSP Peaking System. Energy Procedia, 69, pp 1431-1440.

Sklar-Chik, M. D., Brent, A. C. \& de Kock, I. H. 2016. Critical review of the levelised cost of energy metric. South African Journal of Industrial Engineering, 27, pp 124-133.

South African Forestry Company (SOC) Limited. 2014. SAFCOL Integrated Report 2013/2014.

South African Wind Energy Association. 2015. Reaping reward - South Africa's REIPPPP [Online]. South Africa: Energyblog. Available: http://energy.org.za/reipppp/246reaping-rewards-sa-reippp [Accessed 24 January 2016]. 
TAPPSA Journal 2013. Sappi serious about energy co-generation and saving. TAPPSA Journal, 3, pp 1.

Tidball, R., Bluestein, J., Rodriguez, N. \& Knoke, S. 2010. Cost and Performance Assumptions for Modeling Electricity Generation Technologies. NREL, (Fairfax, Virginia).

United States. Minerals Management Service 2009. Cape Wind Energy Project: Environmental Impact Statement.

US Energy Information Administration. 2013. Feed-In Tariffs and similar programs [Online]. United States of America: US Energy Information Administration. Available: $\quad$ https://www.eia.gov/electricity/policies/provider programs.cfm [Accessed 21 May 2016].

Verkerk, P. J., Anttila, P., Eggers, J., Lindner, M. \& Asikainen, A. 2011. The realisable potential supply of woody biomass from forests in the European Union. Forest Ecology and Management, 261(11), pp 2007-2015.

Vezzoni, C. 2015. Secondary analysis in the social sciences and its relation to futures studies. On the Horizon, 23(2), pp 128-139.

Voivontas, D., Assimacopoulos, D. \& Koukios, E. G. 2001. Aessessment of biomass potential for power production: a GIS based method. Biomass and Bioenergy, 20(2), pp 101-112.

Walwyn, D. \& Brent, A. 2015. Renewable Energy Gathers Steam in South Africa. Renewable and Sustainable Energy Reviews, 41, pp 390-401.

Wang, Y. 2006. Renewable energy in Sweden: an analysis of policy and regulations. Energy Policy, 34, pp 12.

Winkler, H., Hughes, A. \& Haw, M. 2009. Technology learning for renewable energy: Implications for South Africa's long term mitigation scenarios. Energy Policy, 37, pp 10.

World Bank Group. 2011. Purchasing Power Parities and the Real Size of World Economies. A Comprehensive Report of the 2011 International Comparison Program, (1818 H Street NW, Washington DC).

Xu, J. \& Yuan, Z. 2015. An overview of the biomass energy policy in China [Online]. China: BE Sustainable. [Accessed 21 May 2017].

York Timbers. 2013. International Sawmill and Lumber Cost Benchmarking. In: Presentation, Y. I. (ed.) Global Timber/Sawmilling/Lumber cost Benchmarking report::Wood Markets 2012 Annual basis \& Q1/2013. 
511 Table A.1: Determining international LCOE figures

\begin{tabular}{|c|l|c|c|c|}
\hline Country/Region & \multicolumn{1}{|c|}{ Source } & WC & MLC & BC \\
\hline \multirow{5}{*}{ Europe } & $\begin{array}{l}\text { Laleman et al. } \\
(2012)\end{array}$ & 1.7654 & 1.65676 & 1.65676 \\
\cline { 2 - 5 } & $\begin{array}{l}\text { Kost et al. } \\
(2013)\end{array}$ & 2.96145171 & 2.41048395 & 1.85951619 \\
\hline & MEDIAN & $\mathbf{2 . 3 6 3 4 2 5 8 5 5}$ & $\mathbf{2 . 0 3 3 6 2 1 9 7 5}$ & $\mathbf{1 . 7 5 8 1 3 8 0 9 5}$ \\
\hline \multirow{5}{*}{ Canada } & $\begin{array}{l}\text { Kumar et al. } \\
(2003)\end{array}$ & 1.082103807 & 0.863965421 & 0.810031993 \\
\hline & $\begin{array}{l}\text { Kumar et al. } \\
(2008)\end{array}$ & 0.942662867 & 0.902889681 & 0.870661891 \\
\hline & MEDIAN & $\mathbf{1 . 0 1 2 3 8 3 3 3 7}$ & $\mathbf{0 . 8 8 3 4 2 7 5 5 1}$ & $\mathbf{0 . 8 4 0 3 4 6 9 4 2}$ \\
\hline \multirow{5}{*}{ United States } & $\begin{array}{l}\text { Roth Ambs } \\
\text { and } \\
(2004)\end{array}$ & 3.105949009 & 1.740358205 & 1.589766738 \\
\hline & $\begin{array}{l}\text { Borin et al. } \\
(2010)\end{array}$ & 1.523638936 & 1.358921214 & 1.194203491 \\
\hline & MEDIAN & $\mathbf{1 . 5 2 3 6 3 8 9 3 6}$ & $\mathbf{1 . 3 5 8 9 2 1 2 1 4}$ & $\mathbf{1 . 1 9 4 2 0 3 4 9 1}$ \\
\hline \multirow{2}{*}{ China } & $\begin{array}{l}\text { Ouyang and } \\
\text { Lin (2014) }\end{array}$ & $\mathbf{1 . 5 7 5 8 8 3 0 6 3}$ & $\mathbf{1 . 4 9 7 1 9 6 6 9 9}$ & $\mathbf{1 . 4 1 8 5 1 0 3 3 6}$ \\
\hline $\begin{array}{l}\text { Tidball et al. } \\
(2010)\end{array}$ & 1.290924947 & 1.139051424 & 0.835304377 \\
\hline & $\begin{array}{l}\text { Frydas (2010) } \\
\text { International } \\
\text { Renewable } \\
\text { Energy } \\
\text { Agency (2012) }\end{array}$ & 3.400255082 & 3.138696998 & 2.877138915 \\
\hline MEDIAN & 3.980678302 & 2.402133458 & 0.823588614 \\
\hline \multirow{2}{*}{ Global } & $\mathbf{3 . 4 0 0 2 5 5 0 8 2}$ & $\mathbf{2 . 4 0 2 1 3 3 4 5 8}$ & $\mathbf{0 . 8 3 5 3 0 4 3 7 7}$ \\
\hline
\end{tabular}


513 Table A.2: Determining international sales tariffs

\begin{tabular}{|c|c|c|c|c|}
\hline Country/Region & Source & WC & MLC & BC \\
\hline \multirow{4}{*}{ Europe } & $\begin{array}{l}\text { Council of } \\
\text { European } \\
\text { Energy } \\
\text { Regulators } \\
(2015)\end{array}$ & 0.18087125 & 1.20246838 & 2.522092008 \\
\hline & $\begin{array}{l}\text { Lang and Lang } \\
(2014)\end{array}$ & 0.79443 & 1.324729 & 1.855028 \\
\hline & $\begin{array}{l}\text { Lapierre and } \\
\text { Bellisaire } \\
(2011)\end{array}$ & 1.52259479 & 1.67483552 & 1.827076254 \\
\hline & MEDIAN & 0.79443 & 1.324729 & 1.855028 \\
\hline \multirow{3}{*}{ Canada } & $\begin{array}{l}\text { Moore et al. } \\
(2013)\end{array}$. & 1.28058476 & 1.31998737 & 1.359389976 \\
\hline & $\begin{array}{l}\text { Government of } \\
\text { Nova Scotia } \\
(2011)\end{array}$ & 1.86202645 & 1.86202645 & 1.862026445 \\
\hline & MEDIAN & 1.571305603 & 1.591006907 & 1.610708211 \\
\hline China & $\begin{array}{l}\text { Xu and Yuan } \\
(2015)\end{array}$ & 1.54626034 & 1.54626034 & 1.546260338 \\
\hline \multirow{4}{*}{ United States } & US Energy & 0.41338135 & 0.77164518 & 1.129909009 \\
\hline & $\begin{array}{l}\text { Administration } \\
(2013)\end{array}$ & 1.33138063 & 2.26334708 & 3.195313519 \\
\hline & $\begin{array}{l}\text { Couture and } \\
\text { Cory (2009) }\end{array}$ & 1.2797736 & 1.2797736 & 1.279773595 \\
\hline & MEDIAN & 1.279773595 & 1.279773595 & 1.279773595 \\
\hline
\end{tabular}

514

515

516

517

518

519

\section{Appendix B}

Table B.1: Inflation rates used throughout study

\begin{tabular}{|c|c|c|c|c|c|c|c|}
\hline & Canada & $\begin{array}{c}\text { South } \\
\text { Africa }\end{array}$ & Germany & $\begin{array}{c}\text { United } \\
\text { States }\end{array}$ & China & Italy & England \\
\hline 1998 & 1.00 & 6.86 & 0.36 & 1.55 & -0.77 & 1.96 & 1.59 \\
\hline 1999 & 2.63 & 5.27 & 1.19 & 2.19 & -1.4 & 1.66 & 1.34 \\
\hline 2000 & 3.2 & 5.33 & 2 & 3.38 & 0.35 & 2.54 & 0.79 \\
\hline 2001 & 0.72 & 5.73 & 1.61 & 2.83 & 0.73 & 2.79 & 1.24 \\
\hline 2002 & 3.8 & 9.47 & 1.14 & 1.59 & -0.73 & 2.46 & 1.26 \\
\hline 2003 & 2.08 & 5.84 & 1.12 & 2.27 & 1.13 & 2.67 & 1.36 \\
\hline 2004 & 2.13 & -0.68 & 2.22 & 2.68 & 3.84 & 2.21 & 1.34 \\
\hline 2005 & 2.09 & 2.06 & 1.41 & 3.39 & 1.78 & 1.98 & 2.05 \\
\hline 2006 & 1.67 & 3.24 & 1.39 & 3.24 & 1.65 & 2.09 & 2.33 \\
\hline 2007 & 2.38 & 6.17 & 3.17 & 2.85 & 4.82 & 1.83 & 2.32 \\
\hline 2008 & 1.16 & 10.04 & 1.13 & 3.85 & 5.97 & 3.35 & 3.61 \\
\hline 2009 & 1.32 & 7.26 & 0.81 & -0.34 & -0.72 & 0.78 & 2.17 \\
\hline 2010 & 2.35 & 4.1 & 1.31 & 1.64 & 3.17 & 1.52 & 3.29 \\
\hline 2011 & 2.3 & 5.01 & 1.98 & 3.16 & 5.53 & 2.78 & 4.48 \\
\hline 2012 & 0.83 & 5.75 & 2.04 & 2.07 & 2.71 & 3.04 & 2.83 \\
\hline 2013 & 1.24 & 5.77 & 1.43 & 1.47 & 2.62 & 1.22 & 2.53 \\
\hline
\end{tabular}




\begin{tabular}{|l|l|l|l|l|l|l|l|}
\hline 2014 & 1.47 & 6.13 & 0.19 & 1.62 & 2 & 0.24 & 1.47 \\
\hline 2015 & 1.61 & 4.51 & 0.28 & 0.12 & 1.46 & 0.04 & 0.05 \\
\hline
\end{tabular}

Adopted from inflation.eu (2016)

523 Table B.2: Exchange rates and PPP rates (2015) for South African rand

\begin{tabular}{|l|c|c|c|}
\hline \multicolumn{1}{|c|}{ Country } & Currency & Exchange Rate & PPP \\
\hline Canada & C\$1 & 9.73 & 4.37 \\
\hline Germany & 1 Euro & 13.58 & 6.94 \\
\hline Italy & 1 Euro & 13.58 & 7.20 \\
\hline United States of America & US\$1 & 12.26 & 5.39 \\
\hline China & CNY 1 & 1.75 & 1.53 \\
\hline Great Britain & $\begin{array}{c}\text { 1 British } \\
\text { Pound }\end{array}$ & 15.00 & 7.71 \\
\hline
\end{tabular}

